\title{
Benthic invertebrates nestedness in flood and drought periods in a Neotropical floodplain: looking for the richest environments
}

\author{
Aninhamento dos invertebrados bentônicos em períodos de cheia e seca em uma \\ planície de inundação Neotropical: em busca dos ambientes mais ricos
}

Gisele Daiane Pinha ${ }^{1 *}$, Danielle Katharine Petsch ${ }^{1,2}$, Flávio Henrique Ragonha ${ }^{1,3}$, Renata Guglielmetti ${ }^{1}$, Camila Gentilin Bilia ${ }^{1}$, Rafael Prandini Tramonte ${ }^{1}$ and Alice Michiyo Takeda ${ }^{1}$

${ }^{1}$ Programa de Pós-graduação em Ecologia de Ambientes Aquáticos Continentais, Universidade Estadual de Maringá - UEM, Av. Colombo, 5790, CEP 87020-900, Maringá, PR, Brazil

${ }^{2}$ Pós-graduação em Ecologia e Evolução, Universidade Federal de Goiás - UFG, Goiânia, GO, Brazil

${ }^{3}$ Universidade Estadual de Maringá - UEM, Av. Colombo, 5790, CEP 87020-900, Maringá, PR, Brazil

*e-mail: pinha.gd@gmail.com

Cite as: Pinha, G.D. et al. Benthic invertebrates nestedness in flood and drought periods in a Neotropical floodplain: looking for the richest environments. Acta Limnologica Brasiliensia, 2016, vol. 18, e8.

Abstract: Aim: Floodplains are among the most biologically diverse systems in the world, where hydrological regime is recognized as crucial to structure aquatic communities. We predicted that i) structure of benthic metacommunity is nested in the drought and random in the flood season in a Neotropical floodplain. We expected to find ii) environmental homogenization during the flood season which may disrupt the nested pattern. Moreover, we identified habitats of high taxa richness of benthic invertebrates and characterized them by habitat type and fluvial systems. Methods: We sampled benthic invertebrates from 36 habitats in the Upper Paraná River floodplain. We tested nestedness using NODF index and evaluated the environmental variability using the multivariate homogeneity of group dispersions (PERMDISP), separately for flood and drought periods. Results: The environmental variability was lower during the flood. We found a nested distribution among benthic invertebrates in both flood and drought periods. The highest species richness values were recorded in small and unconnected lakes from Paraná fluvial system and some rivers and secondary channels, independent of the fluvial system. Chironomidae, Oligochaeta and Ostracoda were the most frequent taxa and were recorded in all habitats. Conclusion: The nested distribution of benthic invertebrates is a consistent pattern for this metacommunity because its distribution was not disrupted by floods that homogenize limnological conditions and increase the connectivity among habitats. We also found that habitats with high taxa richness were both lotic and lentic in the three fluvial systems. Our findings emphasize that different habitats in different subsystems sustains the richness of the benthic invertebrates metacommunity in the Upper Paraná River floodplain over time.

Keywords: environmental homogenization; Upper Paraná River floodplain; distribution patterns; aquatic invertebrates.

Resumo: Objetivo: Planícies de inundação estão entre os sistemas biológicos mais diversos do mundo, onde o regime hidrológico é reconhecido como crucial para estruturar as comunidades aquáticas. Nós predizemos que i) a estrutura da metacomunidade bentônica é aninhada na seca e aleatória na cheia de uma planície de inundação Neotropical. Nós esperamos encontrar ii) uma 
homogeneização ambiental durante a inundação, a qual desestrutura o padrão aninhado. Além disso, identificamos áreas de maior riqueza de invertebrados bentônicos sob alta heterogeneidade de uma planície de inundação Neotropical, e caracterizamos tais locais por tipo de ambiente e sistema fluvial. Métodos: Nós amostramos 36 locais, e analisamos a estrutura da comunidade bentônica através do índice de aninhamento NODF. A heterogeneidade ambiental foi avaliada através de testes de homogeneidade de dispersóes multivariadas (PERMDISP) separadamente para os períodos de cheia e seca. Resultados: A comunidade bentônica seguiu uma distribuição aninhada em ambos os períodos hidrológicos. As maiores riquezas de táxons foram encontradas nas lagoas pequenas e náo conectadas do sistema fluvial do rio Paraná e em alguns rios e canais secundários, independentemente do sistema fluvial. Chironomidae, Oligochaeta e Ostracoda foram os táxons mais frequentes, registrados em todos os ambientes. A variabilidade ambiental foi menor durante a cheia. Conclusóes: A distribuição aninhada é um padrão consistente para esta metacomunidade bentônica, pois sua distribuiçáo não foi desestruturada mesmo sob condiçóes de homogeneização limnológica e aumento da conectividade dos ambientes promovidos pela cheia. Nós também encontramos que locais com alta riqueza de espécies foram distribuídos tanto entre ambientes lênticos quanto lóticos pertencentes aos três sistemas fluviais. Os resultados demonstram a importância da planície de inundação como um todo, onde a conservação de seus diferentes ambientes mantém a riqueza da comunidade bentônica ao longo do tempo.

Palavras-chave: homogeneização ambiental; planície de inundação do alto rio Paraná; padrôes de distribuição; invertebrados aquáticos.

\section{Introduction}

One of the main objectives of community ecology and biogeography is to explain the non-random distribution of species among sites (Heino et al., 2009). Accordingly, the search for patterns of biological metacommunities distribution and the mechanisms promoting changes in the species composition and richness have been the focus of many studies (Leibold et al., 2004; Cadotte et al., 2006; Presley et al., 2011). One well studied and important distribution pattern in metacommunities is nestedness, where species poor assemblage is a subset of the set of species that occur in rich assemblages (Patterson \& Atmar, 1986). In a perfect nestedness distribution, all species present in a site will be found in all sites with higher species richness (Moore \& Swihart, 2007). A nested pattern has been found in different habitats and organismal groups, such as networks of interactions between animals and plants (Guimarães et al., 2006), the occurrence of species on islands (Frick et al., 2009) and aquatic insect communities in streams (Heino et al., 2009). These disparate examples sustain the idea that nestedness is a common pattern in nature (Wright et al., 1998; Omesová et al., 2008; Heino et al., 2009).

Floodplain systems are among the most biologically diverse areas in the world (Tockner \& Stanford, 2002). In the Neotropics, the Upper Paraná River floodplain is an area of significant ecological importance, because it encompasses a high heterogeneity of habitats (Thomaz et al., 2007), such as connected or unconnected lakes, backwaters, secondary channels and the main channels, which maintain great biodiversity of terrestrial and aquatic organisms (Agostinho et al., 2008). Benthic invertebrates is one of the most diverse and abundant groups among the aquatic communities in the Upper Paraná River floodplain. These organisms are strongly influenced by environmental conditions and show reduced mobility in the water (Würdig et al., 2007), features that make this community an interesting tool for studies of distribution patterns.

The flood pulse is a key process in the structuring of the aquatic communities from the Upper Paraná River floodplain (Agostinho et al., 2008). After floods, the communities may be initially disassembled (i.e. random) and then increase progressively their organizations (Fernandes et al., 2009; Ortega et al., 2015). Indeed, floods may act as natural perturbations in Neotropical floodplains causing random redistribution of some communities during flooding (e.g., Ortega et al., 2015) in opposition to drought, when the metacommunities can be found in some non-random pattern (i.e. nestedness) due to higher environmental variability. Furthermore, during floods, the physical and chemical aquatic conditions tend to become homogenized in floodplains (Thomaz et al., 2007). In this sense, we could expect that this lower environmental variability and higher connectivity may promote a random distribution of organisms during the flood.

We hypothesized environmental homogenization during the flood and predicted that i) environmental variability is lower during the flood than during the drought. In this way, we also investigated the 
hypothesis that the benthic metacommunity is more structured during the drought than during the flood and we tested the prediction that ii) benthic metacommunity is nested during the drought due to higher environmental variability. We also aimed to identify habitats of higher taxa richness of benthic invertebrates in the Upper Paraná River floodplain, and characterize them by type of environment (connected or unconnected lakes, rivers or secondary channels) or fluvial systems (Paraná, Baía or Ivinhema fluvial systems).

\section{Materials and Methods}

\subsection{Study area}

The Upper Paraná River floodplain occupies a vast area, located in a stretch of $230 \mathrm{~km}$ between the mouths of Paranapanema and Ivinhema rivers in Paraná and Mato Grosso do Sul States (Souza Filho \& Stevaux, 2004). The Upper Paraná River floodplain is shows high environmental heterogeneity and high biological diversity. We sampled 36 different sites including lakes with (connected) or without connection (unconnected) to the main river, and main (rivers) and secondary channels belonging to three different fluvial systems: Ivinhema, Baía and Paraná (Figure 1).

\subsection{Sampling period}

We sampled in March of 2010 during the flood period (Figure 2). The water level of the Paraná River reached more than $3.5 \mathrm{~m}$ during the sampling period and attained $6 \mathrm{~m}$ some days before sampling, which is an uncommon event in this floodplain due to flood regulation imposed by the dam operations upstream the study area (Souza Filho, 2009). When the Paraná River reaches high levels (i.e., $6 \mathrm{~m}$ ), there is a total overflow, connecting all habitats in the floodplain (Souza Filho, 2009). We also sampled in September of 2010, during the drought period, when water level was below $3.5 \mathrm{~m}$ (Souza Filho, 2009) and the habitats were less connected.

\subsection{Data sample}

We sampled benthic invertebrates using a modified Petersen grab $\left(0.0345 \mathrm{~m}^{2}\right)$. We determined three sites along the habitat transects, from one to another margin, including the central region. In each

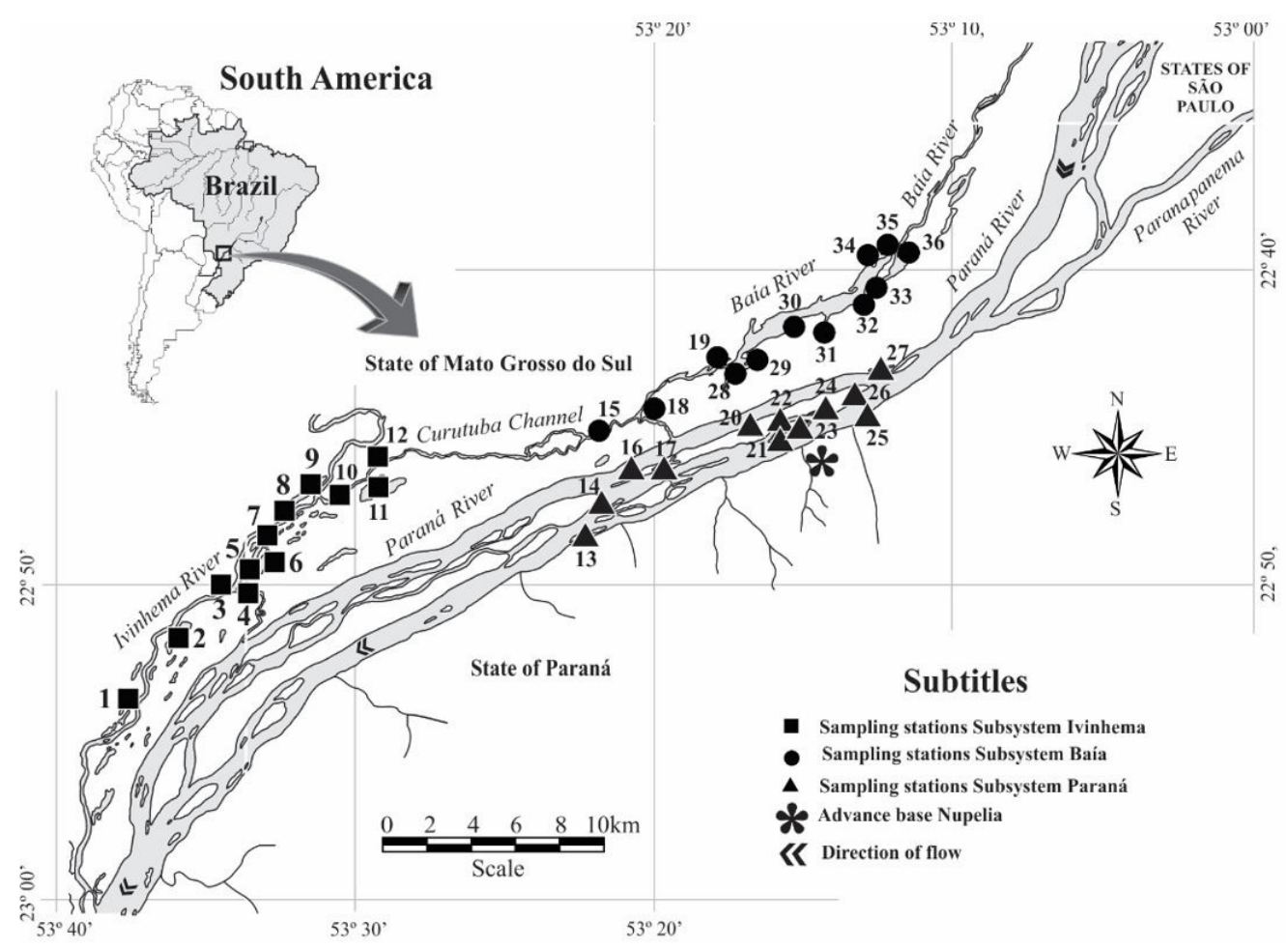

Figure 1. Sampled habitats in the Upper Paraná River floodplain. 1. Peroba L.; 2. Ventura L.; 3. Zé do Paco L.; 4. Ipoitã C.; 5. Boca do Ipoitã L.; 6. Patos L.; 7. Capivara L.; 8. Ivinhema R.; 9. Finado Raimundo L.; 10. Jacaré L.; 11. Sumida L.; 12. Jacaré L.; 13. Cortado C.; 14. Pombas L.; 15. Curutuba C.; 16. Manezinho L.; 17. Osmar L.; 18. Traíra L.; 19. Guaraná L.; 20. Bilé L.; 21. Leopoldo L.; 22. Genipapo L.; 23. Clara L.; 24. Pau Véio L.; 25. Paraná R.; 26. Pousada L.; 27. Garças L.; 28. Baía R.; 29. Fechada L.; 30. Pousada das Garças L.; 31. Porcos L.; 32. Aurélio L.; 33. Baía C.; 34. Maria Luíza L.; 35. Gaviāo L.; 36. Onça L. L. = Lake; C. = Secondary Channel; R. = River. 


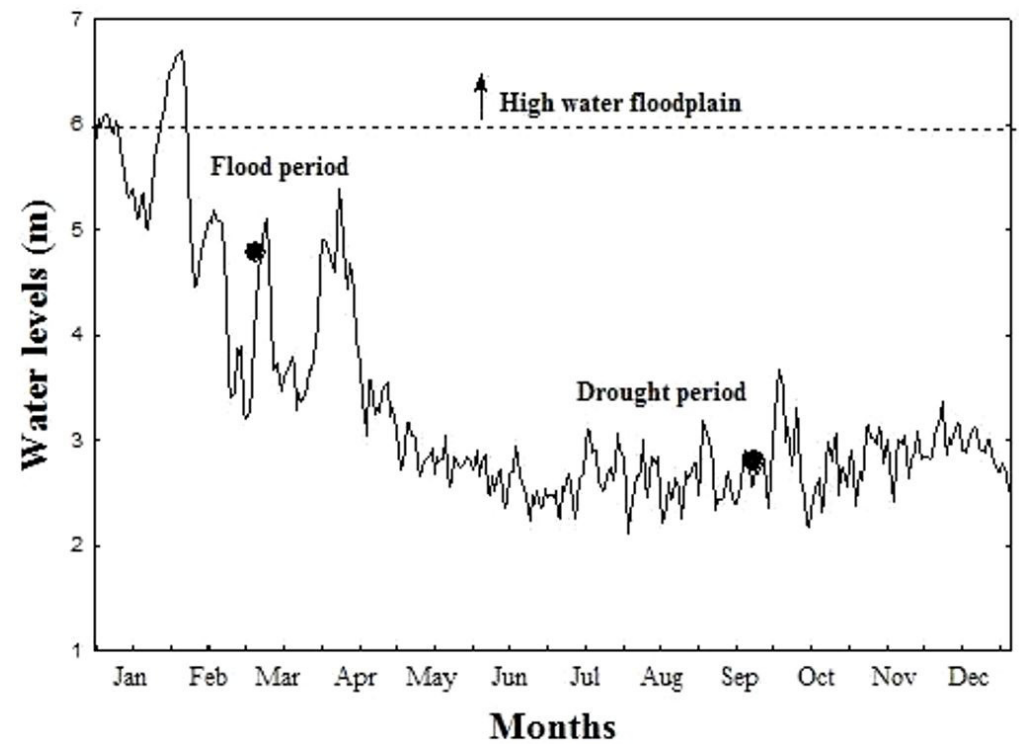

Figure 2. Fluviometric level of the Paraná River in 2010. The circles represent the collection periods. Fluviometric levels exceeding the upper dashed line represent bank overflow.

site, we collected three sample units for biological studies. We washed samples for biological analysis through a series of sieves $(2.0,1.0$ and $0.2 \mathrm{~mm})$. All organisms retained on 2.0 and $1.0 \mathrm{~mm}$ sieves were removed and fixed in $80 \%$ alcohol. We fixed the material retained on the $0.2 \mathrm{~mm}$ sieve in $80 \%$ alcohol and sorted it under a stereomicroscope. All the invertebrates were identified and counted using Pérez (1988) e Mugnai et al. (2010) keys. The taxonomic level of identification varied across groups (i.e., species level, e.g. L. fortunei or phylum, e.g., Nematoda).

The following environmental variables were measured concurrently with the biotic sampling: dissolved oxygen ( $\mathrm{mg} \mathrm{L}^{-1}$, portable oximeter), water temperature $\left({ }^{\circ} \mathrm{C}\right.$, thermometer coupled to the oximeter), electric conductivity $\left(\mu \mathrm{Scm}^{-1}\right.$, portable potentiometer), transparency, $\mathrm{pH}$, turbidity (NTU, portable turbidimeter), total chlorophyll-a ( $\mu \mathrm{g} \mathrm{L}^{-1}$, Golterman et al., 1979), inorganic and organic suspended material $\left(\mu \mathrm{g} \mathrm{L}^{-1}\right.$, Teixeira et al., 1965), total nitrogen ( $\mu g \mathrm{~L}^{-1}$, Mackereth et al., 1978), total phosphorus ( $\mu \mathrm{g} \mathrm{L}^{-1}$, Golterman et al., 1979) and alkalinity ( $\mu \mathrm{Eq} \mathrm{L} \mathrm{L}^{-1}$, Carmouze, 1994). Daily measurements of the water level $(\mathrm{m})$ were obtained using a hydrological ruler at the left margin of the Paraná River in Porto Rico town (Paraná, Brazil).

\subsection{Data analysis}

We investigated if the environmental heterogeneity is different between the hydrological periods using the multivariate homogeneity of group dispersions (PERMDISP; Anderson et al., 2006). In this way, we tested if, in a multidimensional space given by the Principal Coordinates Analysis (PCoA; Anderson \& Walsh, 2013), the mean distance of habitats to its group centroid is lower during the flood than during the drought. We used Euclidian distance to calculate the environmental dissimilarity from abiotic variables measured. Abiotic variables were previously standardized to correct differences among units. The $P$ value was calculated from 999 permutations of model residuals which were used to generate a permutation distribution of $\mathrm{F}$ under the null hypothesis of there being no difference in dispersion between the groups (i.e. flood and drought). We used the function betadisper in vegan package (Oksanen et al., 2010) in the $R$ environment (R Core Team, 2012).

In order to investigate if the structure of the benthic metacommunity is nested during each hydrological period, we calculate the NODF ("Nestedness metric based on Overlap and Decreasing Fill") proposed by Almeida-Neto et al. (2008) and recommended by Ulrich et al. (2009). We ordered the incidence matrix from the most common to the rarest taxa at rows and ranked the habitats from the richest to the poorest at columns. We calculated one NODF among the habitats in the flood and another NODF among the habitats in the drought. We used the function oecosimu in the vegan package (Oksanen et al., 2010) in the $R$ environment (R Core Team, 2012). 


\section{Results}

We corroborated our first hypothesis because we found a lower variability in the abiotic variables during the flood period (average distance to centroid $=2.637$ ) when compared to the drought period (average distance to centroid $=3.421$ ), $\left(\mathrm{F}_{1,70}=4.412 ; P=0.038\right.$ (Figure 3).

We found 31,905 individuals, which are classified in 28 taxa across the 36 sites of Upper Paraná River floodplain. We found 19 taxa of benthic invertebrates in the flood samples and 23 taxa in the drought samples. We observed the highest taxa richness in rivers and channels in both flood and drought periods, with higher values during the drought than the flood season (Table 1). Despite of the low taxa richness found in the most connected and unconnected lakes, we observed increases in the taxa richness from flood to drought periods for both habitats similar to found to rivers and secondary channels. The most common taxa were Chironomidae (found in 30 and 34 sites during the flood and drought seasons, respectively), Nematoda (found in 29 and 30 sites during the flood and drought seasons, respectively), Oligochaeta (found

Table 1. Mean and standard deviation of taxa richness between habitats and hydrological periods.

\begin{tabular}{lrr}
\hline \multirow{2}{*}{\multicolumn{1}{c}{ Habitats }} & \multicolumn{2}{c}{ Taxa Richness } \\
\cline { 2 - 3 } & \multicolumn{1}{c}{ Flood } & \multicolumn{1}{c}{ Drought } \\
\hline Rivers & $10.33( \pm 2.52)$ & $17.00( \pm 2.65)$ \\
Secondary channels & $10.25( \pm 4.57)$ & $14.25( \pm 2.22)$ \\
Connected lakes & $5.47( \pm 2.88)$ & $8.47( \pm 3.18)$ \\
Unconnected lakes & $6.31( \pm 4.70)$ & $9.70( \pm 5.13)$ \\
\hline
\end{tabular}

in 27 and 30 sites during the flood and drought seasons, respectively) and Ostracoda (found in 27 sites in both periods) (Figure 4).

We rejected our second hypothesis about the nestedness of benthic metacommunity only during the drought because we found nestedness for both flood (NODF $=73.82 ; P<0.001)$ as drought $(\mathrm{NODF}=76.14 ; P<0.001)$. The standardized effect size (SES) was similar between periods $(\mathrm{SES}=24.36$ in the flood; SES $=22.37$ in the drought).

\section{Discussion}

Contrary to our second hypothesis, the benthic metacommunity followed a nested distribution among the studied habitats in both hydrological periods, not only for drought as we expected. Corroborating our results, other studies also found the nested distribution for aquatic invertebrates (e.g. Heino, 2010; Heino et al., 2009; Larsen \& Ormerod, 2010; Petsch et al., 2015). Differences in habitat features, such as isolation, size and those features related to environmental quality (i.e., physical and chemical variables) are recognized as drivers of nestedness in many different biological communities (Atmar \& Patterson, 1993; Higgins et al., 2006; Almeida Neto et al., 2008; Elmendorf \& Harrison, 2009). Some of these factors might be important in the Upper Paraná River floodplain, where sites or periods with high environmental heterogeneity (i.e., drought periods) could support more taxa in relation to sites or periods with low environmental heterogeneity (i.e., flood periods) and facilitate the formation of a

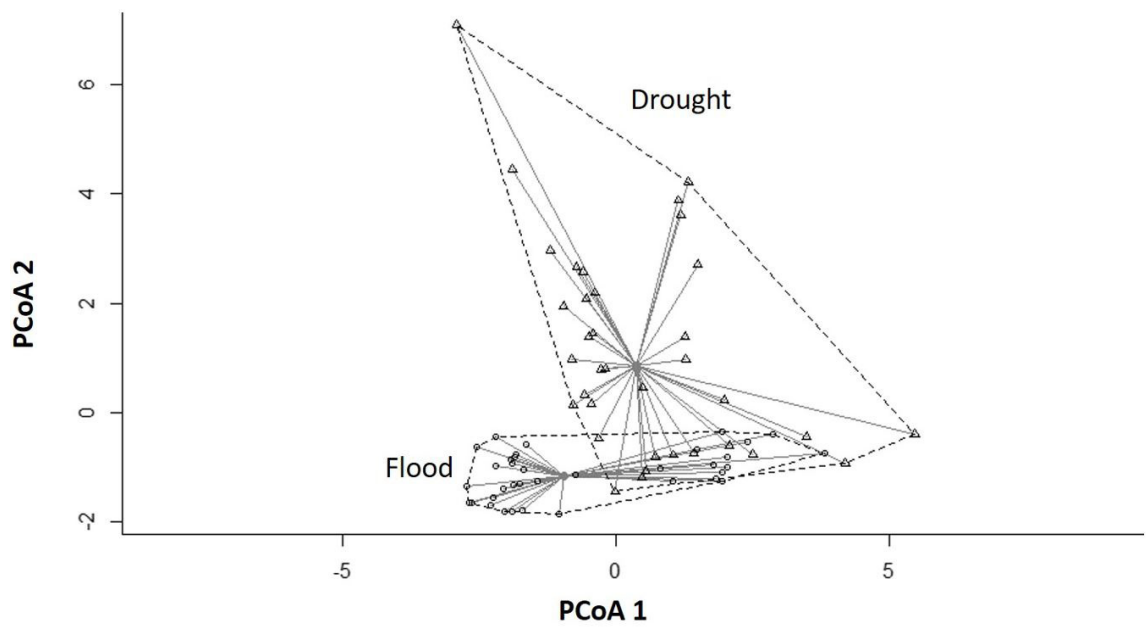

Figure 3. Mean distances to centroid based on differences of abiotic variables between flood and drought periods. Each point on the graph represents the dissimilarity of abiotic variables of an individual lake sampled from different hydrological periods. Triangles represent drought period and circles represent flood period. 

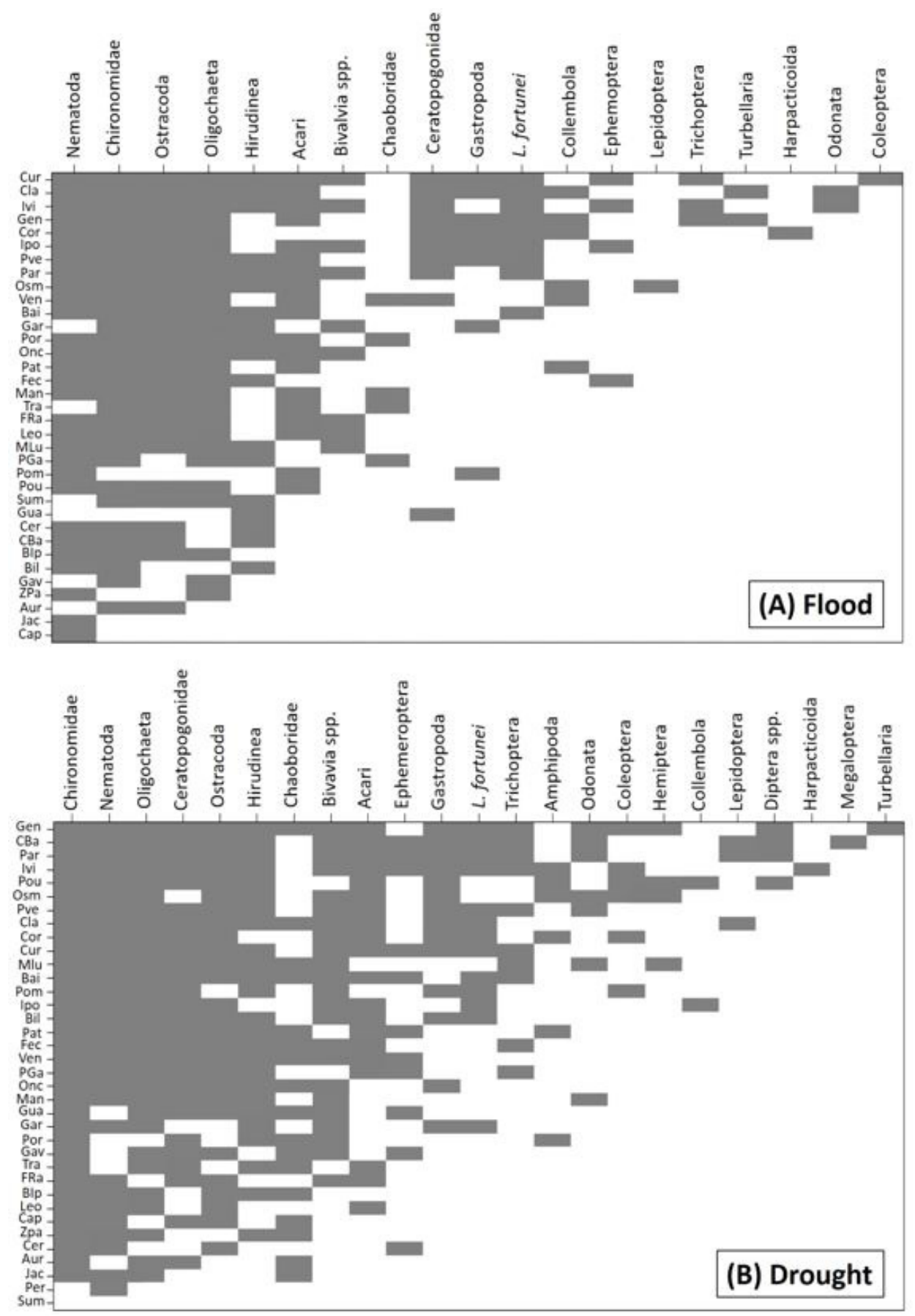

Figure 4. Benthic invertebrates nestedness among the habitats during the flood (A) and during the drought (B). Grey rectangles represent taxa presence.

nested distribution. However, it is unlikely that the nestedness was caused by temporal variability in the physical and chemical water variables among habitats because we found this pattern in both hydrological periods. Although we corroborated our first prediction about environmental homogenization during the flood, the reduced environmental variability was not enough to disrupt the nestedness since both hydrological periods were equally nested. Our results disagree from those found by Ortega et al. (2015) for large-sized fishes using checkerboard. However, maybe using more refined data as morphospecies, NODF differences between hydrological periods (i.e. higher NODF during the drought) become stronger.

There was not a single type of environment (connected or unconnected lakes, rivers or secondary channels) or fluvial system (Paraná, 
Baía or Ivinhema) which sustained higher taxa richness. Nonetheless, both lotic and lentic habitats from the three fluvial systems recorded sites with high taxa richness (e.g., Ivinhema and Paraná Rivers, Curutuba and Ipoitã secondary channels or Genipapo, Clara and Ventura lakes). The high number of taxa found in most rivers and secondary channels can be explained by the fact that these habitats generally have high levels of dissolved oxygen (Roberto et al., 2009). Moreover, the presence of riparian vegetation, both in lotic (e.g., Paraná and Ivinhema rivers, Curutuba and Ipoitão secondary channels) as lentic (e.g., Genipapo, Clara and Osmar lakes) habitats may provide an additional source of organic matter, which represent favorable features to establishment of mostly benthic organisms (as demonstrated by Henriques-Oliveira et al., 1999; Rosin et al., 2010 and Ragonha et al., 2013).

Regarding the benthic metacommunity composition, we found Chironomidae, Oligochaeta and Ostracoda in all 36 habitats analyzed. This high occupancy demonstrated the high environmental plasticity of these benthic invertebrates, which make them able to colonize different habitats in the Upper Paraná River floodplain (i.e. rivers, secondary channels and lakes). Chironomidae, Oligochaeta and Ostracoda have been recognized in other studies as abundant and broadly distributed in the Upper Paraná River floodplain (Takeda, 1999; Higuti \& Takeda, 2002; Higuti et al., 2007, 2009; Rosin et al., 2009; Petsch et al., 2013). Rare taxa (e.g. Harpacticoida, Megaloptera, Turbellaria and Coleoptera) tended to occur, accordingly to the nestedness analyses, in the richest habitats. Moreover, some taxa could be associated to particular habitats. Harpacticoida, for example, is a small crustacean that lives among the interstices of sand grains (Reid, 1991), typical of lotic habitats. Thus, its occurrence was restricted to a few rivers and channels, mainly related to the Paraná River, as demonstrated in other studies (Takeda et al., 2001; Petsch et al., 2013). The invasive mussel Limnoperna fortunei was related to Curutuba and Ipoitã channels and Ivinhema River, environments where the predominance of pebbles provide a suitable substrate for its fixation and establishment.

Studies about nestedness have been applied to evaluate the effectiveness of conservation methods in several ecosystem types (Schouten et al., 2007; Horsak \& Černohorský, 2008) because it is able to detect sites which include the most of species richness in a region. In this way, nestedness analyses are effective tools for resource management and conservation planning because they can suggest whether in theory, any environmental feature of interest, such as those related to flood disturbance (e.g., Petsch et al., 2015) is likely to affect distributional patterns in an array of sites. Despite we could not notice changes in the nestedness pattern between hydrological periods, we identified some very taxa-rich sites of benthic invertebrate in the Upper Paraná River floodplain, among them rivers, secondary channels and some lakes from different fluvial systems. Therefore, our findings emphasize that the maintenance of different habitats in different subsystems sustains the richness of the benthic invertebrates metacommunity in the Upper Paraná River floodplain over time.

\section{Acknowledgements}

We thank the project Long Term Ecological Research/ Conselho Nacional de Desenvolvimento Científico e Tecnológico (PELD/CNPq Process 4280/2010) for financial support. We would like to thank the Coordenação de Aperfeiçoamento de Pessoal de Nível Superior (CAPES) for granting scholarships for postgraduate students and $\mathrm{CNPq}$ for scholarships for undergraduate students. We also thank the Limnology Laboratory of Nupelia/ UEM for providing the abiotic data used.

\section{References}

AGOSTINHO, A.A., PELICICE, F.M. and GOMES, L.C. Dams and the fish fauna of the Neotropical region: impacts and management related to diversity and fisheries. Brazilian Journal of Biology = Revista Brasileira de Biologia, 2008, 68(4, Suppl), 1119-1132. http://dx.doi.org/10.1590/S151969842008000500019. PMid:19197482.

ALMEIDA-NETO, M., GUIMARÁES, P., GUIMARÃES JUNIOR, P.R., LOYOLA, R.D. and ULRICH, W. A consistent metric for nestedness analysis in ecological systems: reconciling concept and measurement. Oikos,, 2008, 17, 1227-1239. http:// dx.doi.org/10.1111/j.0030-1299.2008.16644.x.

ANDERSON, M.J. and WALSH, D.C.I. PERMANOVA, ANOSIM, and the Mantel test in the face of heterogeneous dispersions: What null hypothesis are you testing? Ecological Monographs, 2013, 83(4), 557-574. http://dx.doi.org/10.1890/12-2010.1.

ANDERSON, M.J., ELLINGSEN, K.E. and MCARDLE, B.H. Multivariate dispersion as a measure of beta diversity. Ecology Letters, 2006, 9(6), 683-693. http://dx.doi.org/10.1111/j.14610248.2006.00926.x. PMid:16706913. 
ATMAR, W. and PATTERSON, B.D. On the measure of order and disorder in the distribution of species on archipelagos. Oecologia, 1993, 96(3), 373-382. http://dx.doi.org/10.1007/BF00317508.

CADOTTE, M.W., FORTNER, A.M. and FUKAMI, T. The effects of resource enrichment, dispersal, and predation on local and metacommunity structure. Oecologia, 2006, 149(1), 150-157. http://dx.doi. org/10.1007/s00442-006-0426-z. PMid:16639564.

CARMOUZE, J.P. O metabolismo dos ecossistemas aquáticos: fundamentos teóricos, métodos de estudo e análises químicas. São Paulo: Edgard Blüncher, 1994.

ELMENDORF, S.C. and HARRISON, S.P. Temporal variability and nestedness in California grassland species composition. Ecology, 2009, 90(6), 14921497. http://dx.doi.org/10.1890/08-1677.1. PMid:19569364.

FERNANDES, R., GOMES, L.C., PELICICE, F. and AGOSTINHO, A.A. Temporal organization of fish assemblages in floodplain lagoons: the role of hydrological connectivity. Environmental Biology of Fishes, 2009, 85(2), 99-108. http://dx.doi. org/10.1007/s10641-009-9466-7.

FRICK, F.F., HAYES, P.A. and HEADY, P.A. Nestedness of desert bat assemblages: species composition patterns in insular and terrestrial landscapes. Oecologia, 2009, 158(4), 687-697. http://dx.doi. org/10.1007/s00442-008-1168-x. PMid:18941795.

GOLTERMAN, H.L., CLYMO, R.S. and OHSTAD, M.A.M. Methods for physical and chemical analysis of freshwater. Oxford: Blackwell, 1979.

GUIMARÃES, P.R.J., RICO-GRAY, V., REIS, S.R. and THOMPSON, J.N. Asymmetries in specialization in ant-plantmutualistic networks. Proceeding the Royal Society, 2006, 273(1597), 2041-2047. http://dx.doi. org/10.1098/rspb.2006.3548. PMid:16846911.

HEINO, J. Are indicator groups and cross-taxon congruence useful for predicting biodiversity in aquatic ecosystems? Ecological Indicators, 2010, 10(2), 112-117. http://dx.doi.org/10.1016/j. ecolind.2009.04.013.

HEINO, J., MYRKRA, H. and MUOTKA, T. Temporal variability of nestedness and idiosyncratic species in stream insect assemblages. Diversity \& Distributions, 2009, 15(2), 198-206. http://dx.doi.org/10.1111/ j.1472-4642.2008.00513.x.

HENRIQUES-OLIVEIRA, A.L., SANSEVERINO, A.M. and NESSIMIAN, J.L. Larvas de Chironomidae (Insecta: Diptera) de substrato rochoso em dois rios em diferentes estados de preservação na Mata Atlântica, RJ. Acta Limnologica Brasiliensia, 1999, 11(2), 17-28.

HIGGINS, C.L., WILLING, M.R. and STRAUSS, R.E. The role of stochastic processes in producing nested patterns of species distributions. Oikos, 2006, 114,
159-167. http://dx.doi.org/10.1111/j.2006.00301299.14720.x.

HIGUTI, J. and TAKEDA, A.M. Spatial and temporal variation in densities of Chironomid larval (Diptera) in two lagoons and two tributaries of the Upper Paraná River floodplain, Brazil. Brazilian Journal of Biology = Revista Brasileira de Biologia, 2002, 62(4), 807-818. PMid:12659032.

HIGUTI, J., LANSAC-TÔHA, F.A., VELHO, L.F.M. and MARTENS, K. Biodiversity of non-marine ostracods (Crustacea, Ostracoda) in the alluvial valley of the Upper Paraná Brazil. Brazilian Journal of Biology = Revista Brasileira de Biologia, 2009, 69(2, Suppl), 661-668. http://dx.doi.org/10.1590/S151969842009000300020. PMid:19738972.

HIGUTI, J., VELHO, F.A., LANSAC-TÔHA, L.F.M. and MARTENS, K. Pleuston communities are buffered from regional flood pulses: the example of ostracods in the Paraná River floodplain, Brazil. Freshwater Biology, 2007, 52(10), 1930-1943. http:// dx.doi.org/10.1111/j.1365-2427.2007.01821.x.

HORSAK, M. and ČERNOHORSKÝ, N. Mollusc diversity patterns in Central European fens: hotspots and conservation priorities. Journal of Biogeography, 2008, 35(7), 1215-1225. http://dx.doi.org/10.1111/ j.1365-2699.2007.01856.x.

LARSEN, S. and ORMEROD, S.J. Combined effects of habitat modification on trait composition and species nestedness in river invertebrates. Biological Conservation, 2010, 143(11), 2638-2646. http:// dx.doi.org/10.1016/j.biocon.2010.07.006.

LEIBOLD, M.A., HOLYOAK, M., MOUQUET, N., AMARASEKARE, P., CHASE, J.M., HOOPES, M.F., HOLT, R.D., SHURIN, J.B., LAW, R., TILMAN, D., LOREAU, M. and GONZALEZ, A. The metacommunity concept: a framework for multi-scale community ecology. Ecology Letters, 2004, 7(7), 601-613. http://dx.doi.org/10.1111/j.14610248.2004.00608.x.

MACKERETH, F.Y.H., HERON, J.G. and TALLING, J.J. Water analysis: some revised methods for limnologists. Freshwater Biological Association, 1978, 36, 1-120.

MOORE, J.E. and SWIHART, R.K. Toward ecologically explicit null models of nestedness. Oecologia, 2007, 152(4), 763-777. http://dx.doi.org/10.1007/s00442007-0696-0. PMid:17370091.

MUGNAI, R., NESSIMIAN, J.L. and BAPTISTA, D.L. Manual de identificação de macroinvertebrados aquáticos do Estado do Rio de Janeiro. Rio de Janeiro: Technical Books, 2010. 173 p.

OKSANEN, J., BLANCHET, F.G., KINDT, R., LEGENDRE, P., O'HARA, B., SIMPSON, G.L., SOLYMOS, P., STEVENS, M.H.H. and WAGNER, H. Vegan: Community Ecology Package. 
$R$ package version 1.17-3. Vienna: R Foundation for Statistical Computing, 2010.

OMESOVÁ, M., HORSÁK, M. and HELEŠIC, M. Nested patterns in hyporheic meta-communities: therole of body morphology and penetrability of sediment. Naturwissenschaften, 2008, 95(10), $917-$ 926. http://dx.doi.org/10.1007/s00114-008-0399-3. PMid:18542903.

ORTEGA, J.C.G., DIAS, R.M., PETRY, A.C., OLIVEIRA, E.F. and AGOSTINHO, A.A. Spatiotemporal organization patterns in the fish assemblages of a Neotropical floodplain. Hydrobiologia, 2015, 745(1), 31-41. http://dx.doi.org/10.1007/s10750014-2089-9.

PATTERSON, B.D.E. and ATMAR, W. Nested subsets and the structure of insular mammalian faunas and archipelagos. Biological Journal of the Linnean Society. Linnean Society of London, 1986, 28(1-2), 65-82. http://dx.doi.org/10.1111/j.1095-8312.1986. tb01749.x.

PÉREZ, G.R. Guía para el estúdio de los macroinvertebrados acuáticos del Departamento de Antioquia. Bogotá: Editorial Presencia, 1988. 217 p.

PETSCH, D.K., PINHA, G.D., DIAS, J.D. and TAKEDA, A.M. Temporal nestedness in Chironomidae and the importance of environmental and spatial factors in species rarity. Hydrobiologia, 2015, 745(1), 181-193. http://dx.doi.org/10.1007/ s10750-014-2105-0.

PETSCH, D.K., PINHA, G.D., RAGONHA, F.H. and TAKEDA, A.M. Influência dos fatores ambientais sobre a distribuição da comunidade de invertebrados bentônicos em canais de uma planície de inundação netropical. Biotemas, 2013, 26(3), 127-138. http:// dx.doi.org/10.5007/2175-7925.2013v26n3p127.

PRESLEY, J.S., WILLIG, M.R., BLOCH, C.P., CASTRO-ARELLANO, I., HIGGINS, C.L. and KLINGBEIL, B.T. A complex metacommunity structure for gastropods along an elevational gradient. Biotropica, 2011, 43(4), 480-488. http://dx.doi. org/10.1111/j.1744-7429.2010.00727.x.

R CORE TEAM. R: a language and environment for statistical computing. Vienna: R Foundation for Statistical Computing, 2012.

RAGONHA, F.H., PINHA, G.D., BILIA, C.G., SILVA, R.G., TRAMONTE, R.P. and TAKEDA, A.M. The influence of shoreline availability on the density and richness of Chironomid larvae in Neotropical floodplain lakes. Bioikos, 2013, 27, 67-77.

REID, J.W. The neotropical genus Potamocaris Dussart (Copepoda: Harpacticoida: Parastenocarididae), with descriptions of two new species. Journal of Crustacean Biology, 1991, 11(3), 463-472. http:// dx.doi.org/10.2307/1548472.

ROBERTO, M.C., SANTANA, N.F. and THOMAZ, S.M. Limnology in the Upper Paraná River floodplain: large-scale spatial and temporal patterns, and the influence of reservoirs. Brazilian Journal of Biology = Revista Brasileira de Biologia, 2009, 69(2, Suppl), 717-725. http://dx.doi.org/10.1590/S151969842009000300025 . PMid:19738977.

ROSIN, G.C., OLIVEIRA-MANGAROTTI, D.P. and TAKEDA, A.M. Chironomidae (Diptera) community structure in two subsystems with different states of conservation in a floodplain of southern Brazil. Acta Limnologica Brasiliensia, 2010, 22(3), 276-286. http://dx.doi.org/10.4322/ actalb.02203004.

ROSIN, G.C., OLIVEIRA-MANGAROTTI, D.P., TAKEDA, A.M. and BUTAKKA, C.M.M. Consequences of a dam construction upstream from the Upper Paraná River floodplain (Brazil): temporal analysis of the Chironomidae community over an eight-year period. Brazilian Journal of Biology = Revista Brasileira de Biologia, 2009, 69(2, Suppl), 591-608. http://dx.doi.org/10.1590/S151969842009000300014. PMid:19738966.

SCHOUTEN, M.A., VERWEIJ, P.A., BARENDREGT, A., KLEUKERS, R.J.M. and RUITER, P.C. Nested assemblages of Orthoptera species in the Netherlands: the importance of habitat features and life-history traits. Journal of Biogeography, 2007, 34(11), 1938-1946. http://dx.doi.org/10.1111/j.13652699.2007.01742.x.

SOUZA FILHO, E. and STEVAUX, J.C. Geomorphology of the Paraná River in the reach between the Paranapanema and Ivaí Rivers. In: A. A. AGOSTINHO, L. RODRIGUES, L.C. GOMES, S.M. THOMAZ and L.E. MIRANDA, eds. Structure and functioning of the Paraná River and its floodplain. Eduem, 2004, pp. 8-13.

SOUZA FILHO, E.E. Evaluation of the Upper Paraná River discharge controlled by reservoirs. Brazilian Journal of Biology $=$ Revista Brasileira de Biologia, 2009, 69(2, Suppl), 707-716. http:// dx.doi.org/10.1590/S1519-69842009000300024. PMid:19738976.

TAKEDA, A.M. Oligochaeta community of alluvial upper Paraná River, Brazil: spatial and temporal distribution (1987-1988). Hydrobiologia, 1999, 412, 35-42. http://dx.doi.org/10.1023/A:1003844131148.

TAKEDA, A.M., ROCHA, C.D.F. and STEVAUX, J.C. The influence of water and sediment properties on the occurrence of Potamocaris Dussart, 1979 (Harpacticoida) in the Upper Paraná River (Brazil). Hydrobiologia, 2001, 453-454, 403-409. http:// dx.doi.org/10.1023/A:1013198219922.

TEIXEIRA, C., TUNDISI, J.G. and KUTNER, M.B. Plankton studies in a mangrove: the standing-stock and some ecological factors. Boletim do Instituto Oceanografico, 1965, 24, 23-41.

THOMAZ, S.M., BINI, L.M. and BOZELLI, R.L. Floods increase similarity among aquatic habitats 
in river-floodplain systems. Hydrobiologia, 2007, 579(1), 1-13. http://dx.doi.org/10.1007/s10750006-0285-y.

TOCKNER, K. and STANFORD, J.A. Riverine floodplains: present state and future trends. Environmental Conservation, 2002, 29(03), 308-330. http://dx.doi.org/10.1017/S037689290200022X.

ULRICH, W., ALMEIDA-NETO, M. and GOTELLI, N.J. A consumer's guide to nestedness analysis. Oikos, 2009, 118(1), 3-17. http://dx.doi.org/10.1111/ j.1600-0706.2008.17053.x.

WRIGHT, D.H., PATTERSON, B.D., MIKKELSON, G.M., CUTLER, A. and ATMAR, W. A comparative analysis of nested subset patterns of species composition. Oecologia, 1998, 113(1), 1-20. http:// dx.doi.org/10.1007/s004420050348.

WÜRDIG, N.L., CENZANO, C.S.S. and MOTTAMARQUES, D. Macroinvertebrate communities structure in different environments of the Taim Hydrological System in the state of Rio Grande do Sul, Brazil. Acta Limnologica Brasiliensia, 2007, 4(19), 427-438.

Received: 24 February 2016 Accepted: 16 June 2016 